\title{
The Role of Organizational Cynicism as a Mediator in the Relationship Between Perceived Organizational Support and Counter Productive Work Behavior for Public Employees ${ }^{1}$
}

\section{Kamu Çalışanlarında Örgütsel Destek ve Üretkenlik Karşıtı İş Davranışları Arasındaki İlişskide Örgütsel Sinizmin Aracılık Rolü}

\author{
Tolga BAL* \\ (iD) 0000-0003-1489-5338
}

Sosyal Güvenlik Dergisi / Journal of Social Security

Cilt: 10 Say1: 1 Yıl: 2020 / Volume: 10 Issue: 1 Year: 2020

Sayfa Aralığı: 145-164 Pages: 145-164

DOI: $10.32331 /$ sgd.753051

\begin{abstract}
Public organizations in Turkey adopted working principles such as citizen-orientation, transparency, accountability, efficiency and effectiveness with Law No. 5018 Public Financial Management and Control Law in parallel with the new development trends of giving up the traditional understanding of public administration. The most important factor is human capital in public organizations aiming at ensuring citizen satisfaction. The aim of this study is to examine (and measure) the (inter)relationships between organizational cynicism, perceived organizational support (POS) and counterproductive work behaviors (CWB) and the mediation role of organizational cynicism in predicting CWB by considering the POS premise. The research was carried out with the participation of 419 public employees. The results of this study show that these variables correlate with each other, POS and organizational cynicism predicted CWB and organizational cynicism as a mediator predicts CWB approximately three times stonger with the POS premise and has a mediation role. The results of this research indicates that should take measures to increase POS and reduce organizational cynicism in order to reduce and/or eliminate the CWB. Otherwise, organizational cynicism and CWB will come up there, and the process may result in employees leaving their jobs, which means that to disappear investment of organizations in terms of human resources.
\end{abstract}

Keywords: Perceived organizational support (POS), organizational cynicism, counter productive work behaviors (CWB), structural equation mode (SEM), civil servants

\section{ÖZ}

Türkiye'de kamu örgütleri dünyadaki gelişime paralel olarak geleneksel kamu yönetimi anlayışından vazgeçerek, 5018 sayılı Kamu Mali Yönetim ve Kontrol Kanunu ile vatandaş odaklılık, şeffaflık, hesap verebilirlik, verimlilik ve etkinlik çalışma ilkelerini benimsemişlerdir. Vatandaş memnuniyetini sağlamayı amaçlayan kamu kurum ve kuruluşlarında en önemli unsur ise beşeri sermayedir. $\mathrm{Bu}$ makalede; örgütsel sinizm, algılanan örgütsel destek ve üretkenlik karşııtı iş davranışları (ÜKİD) arasındaki ilişkiler ile örgütsel sinizmin algılanan örgütsel destek öncülü hesaba katılarak ÜKİD'i yordamasındaki aracılık rolü incelenmiştir. Araştırma 419 kamu çalışanının katılımı ile gerçekleştirilmiştir. Araştırma sonucunda, anılan değişkenlerin birbirleriyle ilişkili olduğu, örgütsel sinizmin ve algılanan örgütsel desteğin ÜKİD'i yordadığı, örgütsel sinizmin örgütsel destek algısı öncülü ile ÜKID'i yaklaşık üç kat daha güçlü yordadığı ve aracılık rolünün olduğu tespit edilmiştir. $\mathrm{Bu}$ araştırmanın sonuçları kamu örgütlerinin; ÜKİD'i azaltmak ve/veya ortadan kaldırmak için örgütsel desteği arttıracak ve örgütsel sinizmi azaltacak önlemler almaları gerektiğini göstermektedir. Aksi takdirde örgütsel sinizm ve ÜKİD ortaya çıkacak hatta süreç çalışanların işten ayrılmaları ile sonuçlanabilecektir.

Anahtar Sözcükler: Algılanan örgütsel destek, örgütsel sinizm, üretkenlik karşıtı iş davranışları, yapısal eşitlik modeli, kamu çalışanları

Önerilen atıf şekli: Bal, T. (2020). The Role of Organizational Cynicism as a Mediator in the Relationship Between Perceived Organizational Support and Counter Productive Work Behavior for Public Employees. Sosyal Güvenlik Dergisi (Journal of Social Security). 10(1). 145-164.

\footnotetext{
* Dr., Sosyal Güvenlik Uzmanı, Sosyal Güvenlik Kurumu, tbal@sgk.gov.tr

${ }^{1}$ Bu çalışma Ankara Üniversitesi Sosyal Bilimler Enstitüsü’nde kabul edilen doktora çalışmasından türetilmiştir.
} 


\section{INTRODUCTION}

Nowadays, the productivity of the employees in the organizations operating in the public service sector has been questioned and this situation has started to come up as an important and priority issue. Human capital in public organizations aiming to ensure citizen satisfaction is the most important factor in terms of increasing productivity in organizations. Employee productivity will enable organizations to achieve their goals and objectives and increase the effectiveness \& efficiency of the organization. Work efficiency is also determined by employee productivity.

In this context perceived organizational support (POS), defined as a positive attitude (Eisenberger et al, 1986), organizational cynicism defined as a negative attitude (Dean et all. 1998) towards to the organization and counterproductive work behaviors (CWB) have become topics of discussion and debate among employees and top management. It's thought that POS and cynicism levels of the employees affect the counterproductive work behaviors that may arise in this direction. This means a decrease in productivity. Thus, after the relationship between employees' organizational cynicism attitudes and CWB was determined, it will be possible to increase productivity by taking measures to prevent organizational cynicism.

The aim of this study is to examine (and measure) the (inter)relationships between organizational cynicism, perceived organizational support (POS) and counterproductive work behaviors (CWB) and the mediation role of organizational cynicism in predicting CWB by considering the POS premise. The article consists of three sections: conceptual framework, research methodology and analysis results. Finally, the results were discussed and suggestions were made accordingly.

\section{I- CONCEPTUAL FRAMEWORK}

\section{A- Organizational Cynicism}

The concept of cynicism is a broad concept and has been the subject of different disciplines of social sciences such as philosophy, religion, political science, sociology, psychology and business administration. Since this study is based primarily on "organizational cynicism", it is useful to briefly explain the historical development's terms of cynicism and the definitions made to today.

The concept of cynicism defined as "Antisthenes' doctrine, which argues that human beings can access themselves by virtue and happiness, free from all necessities without being bound to any value" in the Dictionary of Turkish Language Association (TDK, 2019). It's also defined as "An inclination to believe that people are motivated purely by self-interest; skepticism; An inclination to question whether something will happen or whether it is worthwhile; Pessimism; A school of ancient Greek philosophers, the Cynics” in Oxford English Dictionary (OED, 2019). According to the authors who define the terms of organizational cynicism based on this article, cynicism has emerged in ancient Greece as a way of life and a school of thought and has come to our day with different meanings (Brandes, 1997: 7; Dean et al. , 1998: 342).

Today, we can define cynics as "mordacious fault finders" in the simplest terms (Ersoy-Kart, 2015: 83). On the other hand, the existence of many kinds and definitions of cynicism leads to complexity and makes the concept difficult to understand. All of these definitions are true in their own time and discipline or at least not wrong just because important thing is in which field and for what purpose the concept of cynicism is used. For example, if cynicism is defined as a tendency to think that people have hidden goals, to care for others to protect or 
The Role of Organizational Cynicism as a Mediator in the Relationship Between Perceived Organizational Support and Counter Productive Work Behavior for Public Employees

increase their own interests and to manage things (Tokgöz \& Y1lmaz, 2008: 285), we see that this definition represents the Machiavellian view advocated by O'Hair and Cody (1987). This conceptualization of cynicism is not wrong, nor does it involve pure truth.

In this study, the definition of organizational cynicism that detailed in the next subsection is based on "negative attitude of an individual towards his/her organization" made by Dean, Brandes, Dharwadkar (1998), which causes the employee to experience negative cognitive, affective and behavioral (conative) experiences towards his organization, work and ultimately hisself/herself. Organizational cynicism includes "an attitude that includes the belief that the organization lacks integrity" and "negative feelings and humiliating or critical behaviors towards the organization” (Dean, et al., 1998).

\section{B- Components of Organizational Cynicism}

In the literature, the presence of components are accepted in important and strong attitudes as "cognitive, emotional and conative (behavioral)" without hierarchical order among them (Göksu, 2007: 89-105; Güney, 2009: 120-127; Kağıtçıbaş1, 2013: 110-170). In the context of organizational cynicism literature, the authors who focused on this subject until 1996 focused on the cognitive component (Brandes, 1997: 29-30). But after Dean et al. (1997) study covering all three dimensions in 1997, all three components were accepted by many authors (Abraham, 2000; Bernerth, et al., 2007; Brandes \& Das, 2006; Ersoy-Kart, M., 2015; James, 2005; Kağıtçıbaşı, 2013; Kalağan \& Güzeller, 2010; Kalağan, 2009; Neves, 2012). This study is based on these three components as accepted in the literature.

\section{i) Cognitive Component}

The cognitive component, which states "the belief that organizational cynicism is devoid of honesty (Kalağan, 2009: 46), shows the thoughts and beliefs of employees with cynical attitude when examined within the framework of organizational cynicism.

Employees who think and have these beliefs such as practices are devoid of organizational principles, official statements (notifications) are not taken seriously by employees, people are deceitful, selfish insincere, lazy, inconsistent and untrustworthy, employees lie, fraudulent, unscrupulous and immoral behavior and so on. In their organization have the cognitive element of organizational cynicism (Brandes, 1997: 30; Brandes and Das, 2006: 237; Dean et al., 1998: 345-346; Kalağan, 2009: 46).

\section{ii) Affective Component}

The cognitive component that includes emotions which are defined as positive or negative by the individual, arising from cynical beliefs and thoughts; It expresses strong emotional reactions such as disrespect, pain, anger, distress and embarrassment (Brandes and Das, 2006: 237; Dean et al, 1998: 346; Abraham, 2000: 269).

These feelings can spring in cynical employees related to any negative emotions in such cases; A sense of disdain and anger towards their organization, pain, disgust, even shame when they think of their organizations, when they are assigned to a task they do not want or to worry when they are given a job beyond their capacity (Brandes, 1997: 31; Dean et al., 1998: 346).

The concept of contemporary affective component has been expanded by adding an affect of smugness. According to this view, as well as the emotions expressed above, cynical individuals have attitudes such as nurture disdain, frustration and insecurity towards other people or objects and believe that they are superior, more knowledgeable and/or correct than other people (Brandes and Das, 2006: 237; James, 2005: 6). 


\section{iii) Conative Component}

Finally, the conative (behavioral) component expresses the inclination and probability of cynic attitude to behavior. In this context, cynical employees can behave negatively, often humiliating people by using humor, which is their most effective weapon, and making cynical comments about the business environment, the aims of their organizations and their job descriptions (Brandes, 1997: 34-35; Dean et al., 1998: 346).

In addition, behaviors of cynical employees can be an example of the conative component such as constantly complaining about their organization, criticizing everything, meaningful gaze, grinning and smiling in a condescending way (Brandes and Das, 2006: 240).

Cynical employees do not stand behind their organization when it is talked negatively or unfairly about its organization; on the contrary, it tends to denigrate the organization itself (Dean et al., 1998: 346).

\section{C- Perceived Organizational Support (POS)}

Organizational support theory based on "Social Exchange Theory (Blau, 1964) and The Norm of Reciprocity (Gouldner, 1960) expresses that employee's contribution to the organization and the effort made to the job, in other words, the organization has the necessary features to make the employees happy and feel comfortable (Eisenberger et al, 1986; Eisenberger et al., 2001, Neves, 2012).

Perceived organizational support (POS), which is one of the main elements of the analysis conducted in this study expresses that all the behaviors and attitudes developed by the employee towards the organization due to the value of the employee for organization depending on above-mentioned contributions and efforts. (Eisenberger et al, 1986: 500-501). In other words, POS ( or perception of organizational support) is that employees are aware of the organization's contribution to them, feel themselves safe and feel the presence of the organization stands behind them (Eisenberger et al., 1986: 500-501). POS is influenced by positive or negative policies, norms, procedures and activities that affect the employees of the organization (Eisenberger et al., 2001: 42).

POS increases with the fact that the organization assigns human characteristics to the employees, in other words, does not see them as soulless machine parts, and cares about the personality traits, qualities and capacities of the employees. (Eisenberger et al., 1986: 501).

Thus, employees with high levels of organizational support can internalize decisions and activities carried out within the organization at a higher level. (Rhoades \& Eisenberger, 2002: 699). According to Rhodes and Eisenberger (2002), in order to develop organizational support perception, there must be four important precursors: "organizational justice, administrative support, organizational rewards and work conditions and employee characteristics.”

According to the theory of POS (Eisenberger et al., 1986), employees have general beliefs about the organization and these beliefs include the organization's commitment to the contributions and well-being of employees. (Eisenberger et al., 1986: 503). This definition of Eisenberger et al. is based on the following assumptions (Eisenberger et al., 1986: 503):

- Assuming the employee contributes to the organization,

- The employee's perception that the employee's contribution is considered valuable by the organization and that the organization strives to ensure the employee's wellbeing in return.

Kraimer and Wayne are classified POS as "adjustment POS, career POS, and financial POS" (Kraimer \& Wayne, 2004: 217-218): 
The Role of Organizational Cynicism as a Mediator in the Relationship Between Perceived Organizational Support and Counter Productive Work Behavior for Public Employees

- The adjustment POS is defined as the organization's involvement in the adaptation of the employee (including his family) in the process following the business transfers.

- The career POS is that the organization is concerned with the employee's career need.

- The financial POS is that the organization deals with the financial needs of employees and rewards employees' contributions in terms of compensating and working benefits.

A high level of perceived organizational support may mean that employees perceive the organization as good and positive, if this level is low, they perceive as bad and negative (Eisenberger et al., 1986: 503). This may decrease the POS of employees while increasing organizational cynicism.

For example, employees can create cynical attitudes when they are to do a job effectively and to overcome stressful situations if they have the perception that they cannot get help from the organization and that the organization will not stand behind them. So, the perceived weak organizational support level may lead to a negative emotional bond between the organization and the employees (Byrne \& Hochwarter, 2008: 55).

\section{D- Counterproductive Work Behaviors (CWB)}

Counterproductive work behaviors (CWB) can be simply defined as behaviors that harm the organization and its members (Martinko et al., 2002: 37). Such behaviors may consist of direct-active actions such as sabotage, aggression, theft, physical-verbal assault, as well as indirect-passive actions such as non-compliance, deliberate misconduct, withdrawal, being late, quitting, etc. (Fox et al., 2001: 292, Spector \& Fox, 2005: 152).

CWB were initially called as "deviant behaviors" that is defined as "behaviors that reveal unacceptable violations by breaching important norms and threatening the society" (Robinson \& Bennett, 1995: 556-557). In this context, deviant behaviors, in other words, behaviors that go beyond normal measures, have the potential to cause harm to the organization and / or its members (Robinson \& Bennett, 1995: 556-557).

Figure 1. Scope of Counterproductive Work Behaviors (CWB)

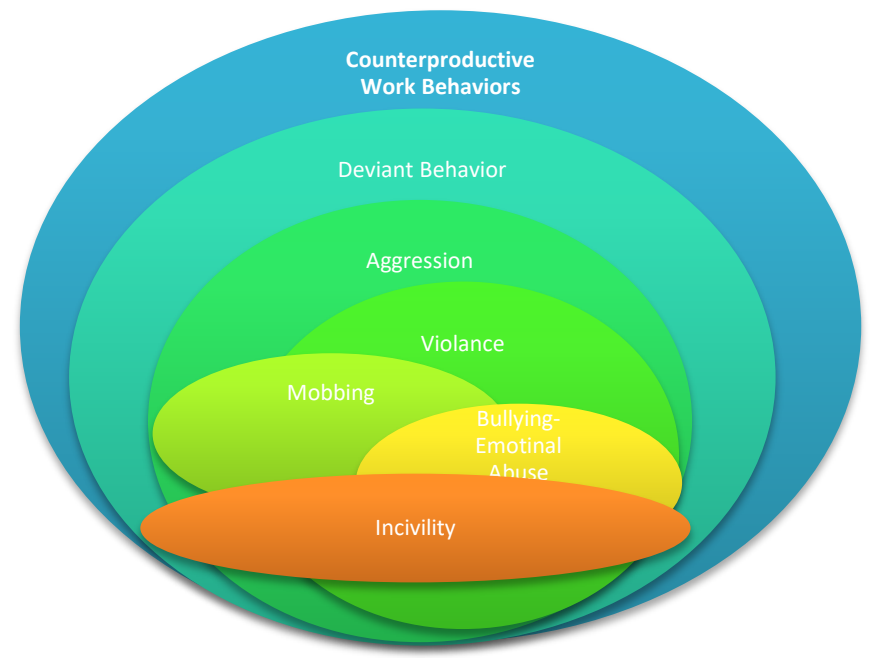

Source: Pearson vd., 2005: 191 
As stated in Figure 1, the scope of the CWB has expanded from the initial conceptualization to the present day and has become a phenomenon that encompasses many concepts. In this context, it is stated that CWB represents these types of behaviors, which include incivility, bullying, emotional abuse, mobbing, (physical) violence, aggression, and deviant bahivors which consist of harmful behaviors towards both the organization and its members (Pearson et al., 2005: 190-191).

Then, concept was further expanded by Spector et al. (2011) and described CWB in five component. According to Spector et al. (2011) classification, which is also based on this study, the CWB consists of five dimensions: abuse against others, production deviance, sabotage, withdrawal and theft (Spector et al., 2006: 448; Spector, 2011: 343).

\section{E- Components of Counterproductive Work Behaviors (CWB)}

This subsection contains detailed core-explanations of the five components of the CWB. While the behavior of abuse against others is mostly considered as the behavior of individual CWB (behavior towards the individual), the production deviance, sabotage, withdrawal and theft behaviors are mostly considered as behaviors of organizational CWB.

\section{i) Abuse Against Others}

Abuse against others (abuse) is defined as an individual behavior that harm colleagues and / or stakeholders within the organization (Spector et al., 2006: 448). These behaviors can consist of physical harm such as humiliation, disdain, disregard, ugly criticism, humiliating comments, intimidation, etc., also can be made up of psychological actions such as ignoring and preventing (secretly) effective working (Spector et al., 2006: 448). However, since direct physical violence is rarely encountered in organizations, many researchers focus on behaviors that do not involve physical harm (Spector et al., 2006: 448).

The concept of abuse here is closely related to such concepts as; incivility, emotional abuse, workplace bullying and psychological mobbing that are in the relevant literature. However, the focus of such studies is on those who target such behavior as incivility, emotional abuse, workplace bullying and psychological mobbing. In the context of CWB studies, the focus is on those who do these behaviors (Spector et al., 2006: 448).

\section{ii) Production Deviance}

The component of production deviance includes behaviors such as not deliberately and properly performing the tasks in the job description of the employee, making mistakes, performing poorly, slowing down and obeying the instructions (Spector et al., 2006: 449).

Spector et al. (2006) approached the concept of production deviance parallel to Hollinger's (1986) view, which classified behaviors such as deliberate absenteeism, perpetually arriving late under production deviance, however Spector et al. deliberately categorized those behaviors under the withdrawal component. (Spector et al., 2006: 449).

Production deviance is considered as more passive and safer type of behavior than sabotage by some researchers because it is a behavior towards organizational goals (non-living beings), not an individual (living beings) (Spector et al., 2006: 449).

\section{iii) Sabotage}

Sabotage behavior is that employees consciously sabotage or destroy (arson, damage property) organizational assets (equipment) to reduce productivity and / or harm the 
The Role of Organizational Cynicism as a Mediator in the Relationship Between Perceived Organizational Support and Counter Productive Work Behavior for Public Employees

organization (Spector et al., 2006: 449). In fact, the sabotage behavior can be considered the expanded version or derivation form of the machine-breaking actions that occurred as a result of the workers' movements after the industrial revolution.

In some studies, sabotage behavior is taken from a wider perspective and defined that is done for the purpose of harming the organizational functioning, disrupting or deflecting the organizational order for the personal interests of the employees, making negative rumors about the organization, embarrassing the organization, slowing production, damaging organizational property, disrupting business relations or damaging customers and employees such as negative behaviors (Ambrose et al., 2002: 948; Skarlicki et al., 2008: 1335).

The sabotage behavior can come into view depending on a number of factors that cause anger or hostile feelings such as the aim of providing individual benefit, drawing attention to any problem, resisting organizational change, gaining the consent of colleagues or gaining superiority over the colleagues (Ambrose et al., 2002: 948; Spector et al., 2006: 449).

\section{iv) Withdrawal}

Withdrawal consists of such as behaviors that deliberately reducing the time limiting the working time of employees: not going to work, coming to work late, leaving early, frequent leave without cause, long-term non-work phone calls, longer breaks than allowed time (coffee, tea, etc.) and non-work appointments (Spector, 2000: 237-238; Spector et al., 2006: 450). In this context, absenteeism of employees as intentional and conscious without any reason, affects organizational motivation and productivity negatively (Spector et al., 2006: 450).

Unlike other CBW components, employees exhibit in this component avoidance (behavior) rather than direct negative behavior to avoid stressors, injustice, dissatisfaction or situations that create negative emotions (Spector, 2000: 237-238; Spector et al., 2006: 450).

Withdrawal is caused by job dissatisfaction (in particular), health problems, psychological disorders, stress, social norms, culture, subordinate-parent conflict, work-family conflict and individual differences (Spector, 2000: 237-238; Spector et al., 2006 450).

Since withdrawal behavior is an attempt to avoid a situation rather than direct harm instead of direct damage, it differs from other counterproductive work behaviors. The individual who exhibits the withdrawal behavior, perhaps does not want to directly harm the organization, in fact, stressors, injustice, dissatisfaction or want to move away from situations that create negative emotions (Spector, 2000: 237-238; Spector et al., 2006: 450).

\section{v) Theft}

The theft, as the last dimension means theft of employees with the idea of harming the organization or individuals. (Spector and Fox, 2002: 271; Spector et al., 2006: 449). Theft behaviors towards the organization may arise due to economic needs, perception of job dissatisfaction, injustice (Mustaine \& Tewksbury, 2002: 113-114) and is not seen as aggressive behavior by many employees (Neuman \& Baron, 1997: 45).

Although it is thought that theft behavior is mostly exhibited becuase of economic interests, theft behavior is considered as an attacking tool against the organization (Spector et al., 2006: 449). In this context, employees do not intend to use or sell the goods they thieved, but rather aim to harm the organization economically. 


\section{II- METHOD OF RESEARCH}

In this study, data were collected by using a questionnaire based on quantitative research method based on scales whose validity and reliability were tested. In this sense, the type of this applied research, which is designed on the basis of field research, can be expressed as relational research.

\section{A- Research Model}

Figure 2 shows the model of this research. As it is seen in Figure 2, which tries to make the conceptual structure of the research problem more understandable with a simple visual, those are examined that the relations between the variables of POS, organizational cynicism, CWB and the mediating role of organizational cynicism in predicting CWB.1

Figure 2. Research Model

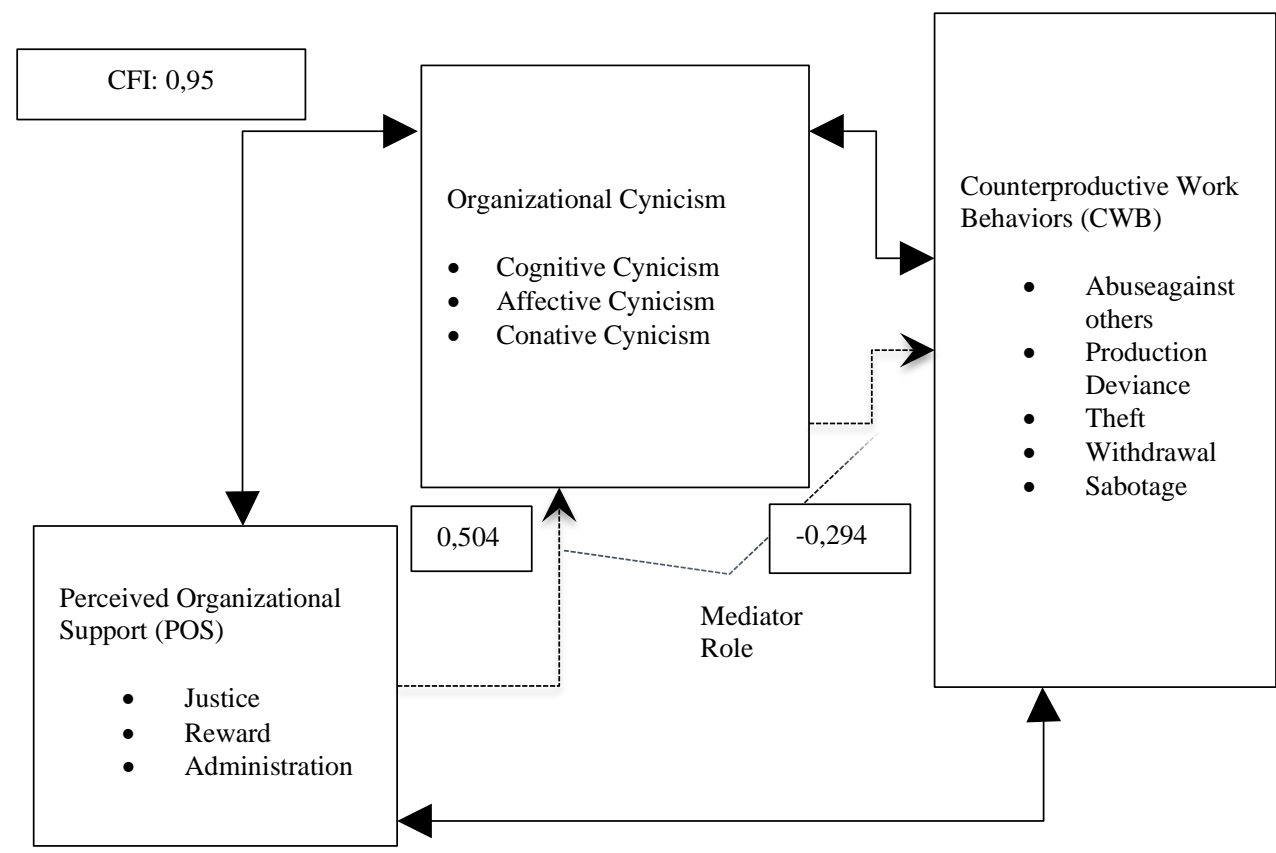

In this context, this model test the hypothesis that the relationship between POS, which is one of the predecessors of organizational cynicism, and CWB will increase by organizational cynicism as mediator. Structural equation model (SEM) was used to test the proposed model.

\section{B- Purpose of Research}

This study aims to examine; the levels of organizational cynicism, POS and representing CWB of public employees some service classes, their relations with each other, how CWB was predicted by organizational cynicism and perception of organizational support and considering the POS premise, the role of organizational cynicism in predicting CWB through SEM.

So, the effects of POS and organizational cynicism on the CWB and the mediating role of organizational cynicism will be seen more clearly. The results will shed light on the measures and steps that must be taken. 


\section{C- Sample}

Systematic sampling method was preferred in order to represent a certain cadre (general administration services, technical services and education and training services) and random sampling method was used for the determination of the persons in these cadres (Yazicioglu \& Erdogan, 2004: 40-50). The sample of the study consists of 419 public employees selected by simple random sampling method.

\section{D- Instruments}

In this study, data were collected in 2016-2017 by using some scales which were tested for validity and reliability in the manuscript based on quantitative research method in order to reach the aforementioned objectives. The scales in the appendix were applied as follows and the data were collected:

- In the first section, through the demographic information of the participants (age, gender, marital status, working time, education level, service class),

- In the second part, through the "Perceived Organizational Support Scale" (Nayır, 2014), based on the scale developed by Eisenberger et al. (1986) with 28 items (questions 1 to 28 on the scale; Cronbach Alpha $(\alpha)=0,94$ ),

- In the third section, through the "Organizational Cynicism Scale" (Kalağan, 2009), based on the scale developed by the Dean et al. (1998) with 13 items (questions 29 to 41 of the scale; Cronbach Alpha $(\alpha)=0,93)$.

- In the fourth section; through the "Counterproductive Work Behavior (CWB) Scale" (Kılıç, 2013) based on the scale developed by Spector et al., (2011) with 40 items (42-81 questions in the scale; Cronbach Alpha $(\alpha)=0,94)$.

The preceived organizational support consist of components of “justice, reward, administration”. Organizational cynicism consist of components of "cognitive cynicism, affective cynicism, conative cynicism". CWB consist of components of "abuse, production Deviance, theft, withdrawal, sabotage”.

\section{III- RESULTS}

\section{A- Demographic Data for Participants}

As shown in Table 1, data were collected from a total of 419 people, 190 female and 229 male participants. $45 \%$ of the participants are women and 55\% are men. Approximately 58\% of the participants are in the 30-34 age range, which is the most intensive age group. The next intensive group is the 22-29 age group, which can be called youth.

Approximately $81 \%$ of the participants got a bachelor degree with 338 people, while $19 \%$ of the participants got a master's degree with 81 people. When the tenure is examined, the dominant group is having service life of $6-10$ years with $65 \%$. This is a natural result of the fact that $80 \%$ of the participants are between $30-40$ years old.

When the distribution of participants according to service class is examined; it is seen that approximately $68 \%$ of them work in general administrative services class, $16.5 \%$ work in education services class and $15 \%$ work in technical services class. 
Table 1. Demographic Data for Participants

\begin{tabular}{|c|c|c|c|}
\hline Data Classification & & Number of People & Percent (\%) \\
\hline \multicolumn{4}{|l|}{ Gender } \\
\hline & Woman & 190 & 45,3 \\
\hline & Man & 229 & 54,7 \\
\hline & Total & 419 & 100,0 \\
\hline \multicolumn{4}{|l|}{ Age } \\
\hline & $22-29$ & 47 & 11,2 \\
\hline & $30-34$ & 244 & 58,2 \\
\hline & $35-39$ & 96 & 22,9 \\
\hline & $40-44$ & 27 & 6,4 \\
\hline & $45-65$ & 5 & 1,2 \\
\hline & Total & 419 & 100,0 \\
\hline \multicolumn{4}{|l|}{ Marital Status } \\
\hline & Single & 141 & 33,7 \\
\hline & Married & 278 & 66,3 \\
\hline & Total & 419 & 100,0 \\
\hline \multicolumn{4}{|l|}{ Educational Level } \\
\hline & Bachelor Degree & 338 & 80,7 \\
\hline & Master's Degree & 81 & 19,3 \\
\hline & Total & 419 & 100,0 \\
\hline \multicolumn{4}{|l|}{ Tenure } \\
\hline & $1-5$ years & 48 & 11,5 \\
\hline & $6-10$ years & 275 & 65,6 \\
\hline & 11-15 years & 67 & 16,0 \\
\hline & 16-20 years & 15 & 3,6 \\
\hline & 20 years and more & 14 & 3,3 \\
\hline & Total & 419 & 100,0 \\
\hline \multicolumn{4}{|l|}{ Service Class } \\
\hline & $\begin{array}{c}\text { Education and } \\
\text { Training Services }\end{array}$ & 69 & 16,5 \\
\hline & $\begin{array}{c}\text { General } \\
\text { Administration } \\
\text { Services }\end{array}$ & 287 & 68,5 \\
\hline & Technical Services & 63 & 15,0 \\
\hline & Total & 419 & 100,0 \\
\hline
\end{tabular}

\section{B- Correlation and Regression Analysis}

\section{i) Examination of Correlations Between Perceived Organizational Support (POS), Organizational Cynicism and CWB}

In this subsection, evaluation of the correlation analysis is located between POS, organizational cynicism and CWB. Those correlations between them are measured by correlation analysis according to (total) scale scores.

\section{ii) Correlation Analysis Between Perceived Organizational Support (POS) and Organizational Cynicism}

As stated results in Table 2, a statistically significant $(\mathrm{p}<0.05)$ relationship was found between all scales except the relationship of reward with conative cynicism. 
The Role of Organizational Cynicism as a Mediator in the Relationship Between Perceived Organizational Support and Counter Productive Work Behavior for Public Employees

Table 2. Correlation Between Perceived Organizational Support (POS) and Organizational Cynicism

\begin{tabular}{|c|c|c|c|c|c|}
\hline \multicolumn{2}{|c|}{ Table of Correlation } & $\begin{array}{l}\text { Cognitive } \\
\text { Cynicism }\end{array}$ & $\begin{array}{l}\text { Affective } \\
\text { Cynicism }\end{array}$ & $\begin{array}{l}\text { Conative } \\
\text { Cynicism } \\
\end{array}$ & $\begin{array}{l}\text { Organizational } \\
\text { Cynicism (Total) }\end{array}$ \\
\hline \multirow[t]{2}{*}{ Justice } & $\mathbf{r}$ &,$- 578 *$ &,$- 451 *$ &,$- 207^{*}$ &,$- 519 *$ \\
\hline & p &, 000 &, 000 &, 000 &, 000 \\
\hline \multirow[t]{2}{*}{ Administration } & $\mathbf{r}$ &,$- 359 *$ &,$- 434^{*}$ &,$- 139 *$ &,$- 399 *$ \\
\hline & p & ,000 & ,000 & ,004 & ,000 \\
\hline \multirow[t]{2}{*}{ Reward } & $\mathbf{r}$ &,$- 421 *$ &,$- 320 *$ &,- 044 &,$- 334 *$ \\
\hline & p & ,000 & ,000 & 0,368 & ,000 \\
\hline \multirow{2}{*}{$\begin{array}{l}\text { Perceived } \\
\text { Organizational } \\
\text { Support (Total) }\end{array}$} & $\mathbf{r}$ &,$- 542 *$ &,$- 470 *$ &,$- 171 *$ &,$- 500 *$ \\
\hline & $\mathbf{p}$ & ,000 & ,000 & ,000 & ,000 \\
\hline
\end{tabular}

${ }^{*} \mathrm{p}<0,05 ; \mathrm{r}<0,3$ is weak, $0,6<\mathrm{r}>0,3$ is moderate $1<\mathrm{r}>0,6$ ise strong; $\mathrm{r}=$ - is inverse relationship

As can be seen in Table 2, the justice component has an inverse correlation between cognitive, affective and organizational cynicism (total) scales as moderate; behavioral cynicism component as weak. Administration component has an inverse correlation between cognitive, affective and organizational cynicism (total) scales as moderate; behavioral cynicism subscale as weak. There is an inverse moderate correlation between the management subscale and cognitive, affective and organizational cynicism (total) scales.

There is an inverse moderate relationship between justice component and cognitive, affective and organizational cynicism (total) scales. The POS (total) scale has an inverse correlation between cognitive, affective and organizational cynicism (total) scales as moderate; behavioral cynicism subscale as weak.

\section{iii) Correlation Analysis Between Perceived Organizational Support (POS) and Counterproductive Work Behaviors (CWB)}

As stated results in Table 3, a statistically significant $(\mathrm{p}<0.05)$ relationship was found between scales of; justice with withdrawal, abuse against others, CWB (total); administration with abuse against others; reward with theft; perceived organizational support (total) with abuse against others and CWB (total).

Table 3. Correlation Between Perceived Organizational Support (POS) and Counterproductive Work Behaviors (CWB)

\begin{tabular}{|c|c|c|c|c|c|c|c|}
\hline $\begin{array}{c}\text { Table of } \\
\text { Correlation }\end{array}$ & & Sabotage & Withdrawal & $\begin{array}{c}\text { Production } \\
\text { Deviance }\end{array}$ & Theft & $\begin{array}{c}\text { Abuse } \\
\text { Against } \\
\text { Others }\end{array}$ & $\begin{array}{l}\text { CWB } \\
\text { Total }\end{array}$ \\
\hline \multirow[t]{2}{*}{ Justice } & $\mathbf{r}$ &,- 031 &,$- 151 *$ &,- 029 &,- 029 &,$- 151 *$ &,$- \mathbf{1 4 0}^{*}$ \\
\hline & $\mathbf{p}$ & ,524 & 002 & ,558 & ,558 & 002 & ,004 \\
\hline \multirow[t]{2}{*}{ Administration } & r & 071 & 014 &,- 016 &,- 035 &,$- 125^{*}$ &,- 048 \\
\hline & p & , 147 & 0,768 & ,751 &, 470 & ,011 & 324 \\
\hline \multirow[t]{2}{*}{ Reward } & $\mathbf{r}$ &,- 038 &,- 040 & ,027 &,$- 132 *$ &,- 057 &,- 053 \\
\hline & $\mathbf{p}$ & ,433 & ,417 & ,584 & ,007 & ,244 & ,279 \\
\hline \multirow{2}{*}{$\begin{array}{l}\text { Perceived } \\
\text { Organizational } \\
\text { Support (Total) }\end{array}$} & $\mathbf{r}$ &,- 004 &,$- 090-$ &,- 015 &,- 059 &,$- 139 *$ &,$- 107 *$ \\
\hline & $\mathbf{p}$ & ,934 & ,066 & ,767 & ,225 & ,004 & ,029 \\
\hline
\end{tabular}

${ }^{*} \mathrm{p}<0,05 ; \mathrm{r}<0,3$ is weak, $0,6<\mathrm{r}>0,3$ is moderate $1<\mathrm{r}>0,6$ ise strong; $\mathrm{r}=$ - is inverse relationship 
In this context, there is an inverse weak correlation between the justice with withdrawal, abuse against others, and CWB (total); administration with abuse against others; the reward with the theft; the perceived organizational support (total) scale with abuse against others and CWB (total).

\section{iv) Correlation Analysis Between Organizational Cynicism and Counterproductive Work Behaviors (CWB)}

As stated results in Table 4, a statistically significant $(\mathrm{p}<0.05)$ relationship was found between all scales except the relationship of cognitive cynicism, theft and sabotage with other sclaes.

Table 4. Correlation Between Organizational Cynicism and Counterproductive Work Behaviors (CWB)

\begin{tabular}{|c|c|c|c|c|c|c|c|}
\hline $\begin{array}{l}\text { Table of } \\
\text { Correlation }\end{array}$ & & Sabotage & Withdrawal & $\begin{array}{l}\text { Production } \\
\text { Deviance }\end{array}$ & Theft & $\begin{array}{l}\text { Abuse } \\
\text { against } \\
\text { others }\end{array}$ & $\begin{array}{l}\text { CWB } \\
\text { Total }\end{array}$ \\
\hline \multirow{2}{*}{$\begin{array}{l}\text { Cognitive } \\
\text { Cynicism }\end{array}$} & $\mathbf{r}$ &,- 022 & ,047 &, 007 &,- 016 & ,072 & ,048 \\
\hline & p & 653 & ,340 & ,892 & ,747 & ,139 & ,326 \\
\hline \multirow{2}{*}{$\begin{array}{l}\text { Affective } \\
\text { Cynicism }\end{array}$} & $\mathbf{r}$ &, 090 & ,105* & ,132* &,- 021 & ,225* & ,175* \\
\hline & $\mathbf{p}$ &, 066 & ,032 & ,007 & 668 & ,000 & 000 \\
\hline \multirow{2}{*}{$\begin{array}{l}\text { Conative } \\
\text { Cynicism }\end{array}$} & $\mathbf{r}$ & 095 & ,131* & ,122* &,- 058 & ,285* & ,206* \\
\hline & $\mathbf{p}$ & ,053 & ,007 & ,013 & ,238 & ,000 &, 000 \\
\hline \multirow{2}{*}{$\begin{array}{l}\text { Organizational } \\
\text { Cynicism } \\
\text { (Total) }\end{array}$} & $\mathbf{r}$ & 069 & ,117* & ,110* &,- 038 &, $241 *$ & ,178* \\
\hline & $\mathbf{p}$ & , 158 & ,017 & ,024 & ,443 & ,000 &, 000 \\
\hline
\end{tabular}

* $\mathrm{p}<0,05 ; \mathrm{r}<0,3$ is weak, $0,6<\mathrm{r}>0,3$ is moderate $1<\mathrm{r}>0,6$ ise strong; $\mathrm{r}=$ - is inverse relationship

In this context, there is a positive weak correlation between the cognitive, conative and organizational cynicism (total) with the withdrawal, production deviance and and CWB (total). In other words, organizational cynicism scales, except cognitive cynicism, are positively \& weakly correlated with all CWB scales except sabotage and theft.

\section{v) Examination of Regressions Between Perceived Organizational Support (POS), Organizational Cynicism and Counterproductive Work Behaivors (CWB)}

In this subsection, evaluation of the regression analysis that based on the total scores of the scales is located between POS, organizational cynicism and CWB. Those regressions between them are measured by regressions analysis according to (average) scale scores.

\section{C- The Regression Between Perceived Organizational Support (POS) and Organizational Cynicism}

As summarized in Table 5, perceived organizational support predicts organizational cynicism $(\mathrm{p}<0.05)$. The strength of this relationship was measured as $25 \%$ (R square $=0.25)$. In other words, perceived organizational support, which is an independent variable, explains $1 / 4$ of organizational cynicism, which is a dependent variable. Although this seems primarily to be a low value, it can be said that it is an explanatory result according to the attitudinal and behavioral scale results. 
The Role of Organizational Cynicism as a Mediator in the Relationship Between Perceived Organizational Support and Counter Productive Work Behavior for Public Employees

Table 5. The Regression Between Perceived Organizational Support (POS) and Organizational Cynicism

\begin{tabular}{|c|c|c|c|c|}
\hline \multicolumn{5}{|c|}{ Linear Regression Analysis: ANOVA } \\
\hline & $\boldsymbol{\beta}$ & R square & St. dev. & Sig.(p) \\
\hline \multirow{2}{*}{$\begin{array}{c}\text { Perceived } \\
\text { Organizational Support } \\
\text { (POS) }\end{array}$} & 60,764 & \multirow{2}{*}{0,25} & 1,533 & 0,000 \\
\hline & $-0,272$ & & 0,023 & \\
\hline \multicolumn{5}{|c|}{ a. The dependent variable $(\gamma)$ : organizational cynicism } \\
\hline \multicolumn{5}{|c|}{ b. Independent variable $\left(\mathrm{X}_{1}\right)$ : perceived organizational support (POS) } \\
\hline
\end{tabular}

\section{D- The Regression Between Perceived Organizational Support (POS) and Counterproductive Work Behaviors (CWB)}

As summarized in Table 6, perceived organizational support (POS) predicts counterproductive work behavior $(\mathrm{CWB})(\mathrm{p}<0.05)$. POS, which is an independent variable, predicts CWB, but the strength of this relationship was measured very low as $1 \%$ (R square $=0.01$ ).

Table 6. The Regression Between Perceived Organizational Support (POS) and Counterproductive Work Behaviors (CWB)

\begin{tabular}{|c|c|c|c|c|}
\hline \multicolumn{5}{|c|}{ Linear Regression Analysis: ANOVA } \\
\hline \multirow{3}{*}{$\begin{array}{c}\text { Perceived } \\
\text { Organizational Support } \\
\text { (POS) }\end{array}$} & $\boldsymbol{\beta}$ & $\mathbf{R}$ square & St. dev. & Sig.(p) \\
\hline & 54,665 & \multirow{2}{*}{0,011} & 2,003 & 0,029 \\
\hline & $-0,107$ & & 0,030 & \\
\hline
\end{tabular}

a. The dependent variable $(\gamma)$ : counterproductive work behaviors (CWB)

b. Independent variable $\left(\mathrm{X}_{1}\right)$ : perceived organizational support (POS)

${ }^{*} \mathrm{p}<0,05$

\section{E- The Regression Between Organizational Cynicism and Counterproductive Work Behaviors (CWB)}

As summarized in Table 7, organizational cynicism predicts counterproductive work behaviors (CWB) $(\mathrm{p}<0.05)$. The strength of this relationship was measured as 3\% (R Square $=0.032$ ), which can be considered as low. So organizational cynicism as an independent variable, explains $3 \%$ of the dependent variable, which is CWB.

Table 7. The Regression Between Organizational Cynicism and Counterproductive Work Behaviors (CWB)

\begin{tabular}{|c|c|c|c|c|}
\hline \multicolumn{5}{|c|}{ Linear Regression Analysis: ANOVA } \\
\hline \multirow{3}{*}{$\begin{array}{l}\text { Organizational } \\
\text { Cynicism }\end{array}$} & $\boldsymbol{\beta}$ & R square & St. dev. & Sig.(p) \\
\hline & 41,652 & \multirow{2}{*}{0,032} & 2,438 & 0,000 \\
\hline & 0,203 & & 0,055 & \\
\hline \multicolumn{5}{|c|}{ a. The dependent variable $(\gamma)$ : counterproductive work behaviors (CWB) } \\
\hline \multicolumn{5}{|c|}{ b. Independent variable $\left(\mathrm{X}_{1}\right)$ : organizational cynicism } \\
\hline $\mathrm{p}<0,05$ & & & & \\
\hline
\end{tabular}




\section{F- The Role of Organizational Cynicism as a Mediator Between Perceived Organizational Support (POS) and Counter Productive Work Behavior (CWB): Structural Equation Model (SEM)}

In this part, organizational cynicism has been tested as a mediator in predicting CWB with the perceived organizational support premise and it has been found out that organizational cynicism has a (partial) mediating role.

First of all, the CWB scale had 0.78 (78\%) score as a result of the CFI (comparative fit index), which is insufficient since the score less than 0.95 , so the "theft" and "sabotage" subcomponents were excluded from the model. This situation is also clearly seen in correlation analysis (see Table 3 and 4).

In this study, the model that's CFI score is 0.95 , was formed by excluding mentioned two subcomponents while constructing structural equality model (SEM). In addition, it is noted that CFI score would be 0.98 if only abuse against others which is the most significant component (subscale) of CWB, left in the model.

According to results of the structural equality model (SEM), which is summarized in Figure 3 and has a score of 0.95 CFI, organizational cynicism as a medaitor predicts CWB consisting of subcomponents of production deviance, withdrawal and abuse against others with POS premise. In other words, POS predicts CWB with organizational cynicism as a mediator.

In the analysis, the parameters of the observable variables are fixed to 1 . In addition, pairs that obtained the best variance were selected from sub-components of organizational support and cynicism scales.

Figure 3. The Role of Organizational Cynicism as A Mediator Between Perceived Organizational Support (POS) and Counter Productive Work Behavior (CWB): Structural Equation Model (SEM)

Perceived Organizational Support (POS)

- Justice

- Reward

- Administration

\section{CWB}

(Counterproductive Work Behaviors)

Cognitive Cynicism

- Affective Cynicism

- Conative Cynicism

- Abuse Against Others

- Production Deviance

- Withdrawal 
The Role of Organizational Cynicism as a Mediator in the Relationship Between Perceived Organizational Support and Counter Productive Work Behavior for Public Employees

In this context, low level of organizational cynicism of the employees with increased perceived organizational support will decrease CWB. On the other hand, as opposed to high level of organizational cynicism of employees with reduced perceived organizational support will increase CWB.

Table 8. Results of Analysis

\begin{tabular}{|c|c|c|c|}
\hline \multicolumn{4}{|c|}{ Results of Analysis } \\
\hline & $\beta$ & R square & Sig.(p) \\
\hline POS - organizational cynicism & $-0,504$ & 0,254 & 0,000 \\
\hline \multicolumn{4}{|c|}{ a. The dependent variable $(\gamma)$ : organizational cynicism } \\
\hline \multicolumn{4}{|c|}{ b. Independent variable $\left(\mathrm{X}_{1}\right)$ : perceived organizational support (POS) } \\
\hline & $\beta$ & R square & Sig.(p) \\
\hline $\begin{array}{l}\text { POS and organizational } \\
\text { cynicism - CWB }\end{array}$ & $-0,294$ & 0,086 & 0,000 \\
\hline \multicolumn{4}{|c|}{ a. The dependent variable $(\gamma)$ : counterproductive work behaviors (CWB) } \\
\hline \multicolumn{4}{|c|}{$\begin{array}{l}\text { b. Independent variables }\left(\mathrm{X}_{1}\right) \text { : perceived organizational support }(\mathrm{POS}) \text { and organizational } \\
\text { cynicism }\end{array}$} \\
\hline
\end{tabular}

According to results of analysis (see Table 8), while the perceived organizational support predicts organizational cynicism, the explanatory power of regression is found to be the same as in regression analysis (see Table 5). But explanatory power of regression in predicting CWB has increased 3 times as 3\% to $9 \%$ for organizational cynicism and 9 times as $1 \%$ to 9\% for POS (see B values in Table 6,7 and 8). This result, as summarized in Figure 3, shows us that organizational cynicism has a (partial) mediator role between POS and CWB.

In other words, POS (\%1) and organizational cynicism (\%3) predict the CWB at a low rate on their own, but predict at a higher rate together in mediator model. This suggests that although an employee who does not get sufficient organizational support, CWB does not immediately merge, CWB merges more often if it is combined with organizational cynicism.

\section{CONCLUSION}

In this paper, it is examined that the mediation role of organizational cynicism in predicting counterproductive work behaviors (CWB) considered perceived organizational support (POS) premise and measured the (inter)relationships between organizational cynicism, POS and CWB. In the context, findings have obtained supporting national and international researches to date (Bernerth et al., 2007; Bluedon, 1982; Byrne \& Hochwarter, 2008; Chiaburu et al., 2013; Çakar \& Yildiz, 2009; Dalal, R.S., 2005; Eaton, 2000; Eisenberger et al., 1986; James, 2005; FitzGerald, 2002; Folger \& Konovsky, 1989; Fox et al., 2001; Lind \& Tyler, 1988; Martin \& Bennett, 1996; Miao, R.T., 2011; Moorman, et al., 1998; Özdevecioğlu, 2003; Sackett, 2002; Rhoades \& Eisenberger, 2002; Tokgöz, N., 2011; Turunç \& Çelik, 2010). However, none of these studies examined POS, organizational cynicism and CWB at the same time, and tested the mediation role of organizational cynicism between POS and CWB.

According to results of the analysis, POS correlated with organizational cynicism as moderate and inverse; CWB as weak and also inverse. In other words, while POS decreases, it suggests that organizational cynicism and CWB increases. There is a weak positive correlation between organizational cynicism and CWB. This result tells us that if there is an increase in the level of organizational cynicism, employees may show more CWB. 
According to the results of the regression analysis, POS explained organizational cynicism by $1 / 4(25 \%)$. Although this may seem primarily to be a low ratio, it can be said that it is an explanatory result according to the attitude and behavioral scale results. This shows that if there is insufficient or no organizational support, it will lead to cynical attitudes and behaviors in employees. This result also supports other research on this subject and proves that POS is a premise of organizational cynicism.

When organizational cynicism is an independent variable in the regression analysis, it also predicts CWB and the strength of the relationship is 3\%. In other words, organizational cynicism explains CWB by 3\% that can be considered low ratio. Finally, in the regression analysis, the POS predicts CWB, but the strength of this relationship is very low at $1 \%$. This result led us to question whether the organizational cynicism has a mediating role in predicting the CWB with POS premise and it will increase the strength of this relationship.

Organizational cynicism, as a mediator in predicting CWB with POS precursor was established and tested by structural equation model (SEM), and POS's the explanatory power to predict organizational cynicism was found to be the same as in regression analysis. But the the explanatory power of organizational cynicism in predicting CWB increased 3 times from $\% 3$ to $9 \%$ and also it increased 9 times for organizational support from $1 \%$ to $9 \%$. Thus, it has been found that organizational cynicism has a (partial) mediating role in that relationship. Therefore, employees with increased (decreased) POS, it led to decrease (increase) organizational cynicism and result of this process there will be a low (high) frequency of CWB, in particular components of withdrawal, production deviance and abuseagainst others.

The above-mentioned results tell us that; to reduce and / or eliminate the CWB, they need to take measures to increase POS and reduce organizational cynicism. In this context, it is necessary to create an ethical climate in organizations, to be fair in the distribution of awards and management, to encourage employees, to give jobs according to the quality of the employees, to provide team support and job satisfaction. Otherwise, the CWB will go up there, and even the process may result in employees quitting (Avşaroğlu et al., 2007: 117; Çekmecelioğlu, H.G., 2005; Schneider \& Snyder, 1975; Ünal et al., 2001) that means the investment made by the organizations in terms of human resources is destroyed.

Many studies indicate that organizational citizenship (extra role) behaviors and / or job performances of employees will arise or increase as a result of increasing POS and / or lowering organizational cynicism (Cohen et al., 2001; Eisenberger et al., 2002; Moorman et al., 1998; Randall et al., 1999; Rhoades \& Eisenberger, 2002; Shanock \& Eisenberger, 2006).

On the other hand, it is also stated that organizational cynicism is not directly related to work performance and organizational citizenship behavior; but psychological agreement and POS is not directly related to work performance but increases performance with organizational identification (Andersson, 1996; Dean et al., 1998; Byrne \& Hochwarter, 2008; Turunç \& Çelik, 2010).

In addition, it should be noted that the results obtained in this study have limitations. In the next studies, other possible predecessors of organizational cynicism and CWB can be examined such as an individual (personality and demographic) or an organizational (psychological contract violation, organizational policies, management style, etc.) in the model. In addition, the next studies may focus on specific sectoral classifications such as public-private, industry-service-agriculture, and these mentioned sectors can be examined individually on a particular subject. 
The Role of Organizational Cynicism as a Mediator in the Relationship Between Perceived Organizational Support and Counter Productive Work Behavior for Public Employees

The organizational citizenship behaviors which can be considered as a positive expression of the CWB, can be tested in a similar model. In addition, it will be healthier to run the model with sufficient sample by targeting only one occupational group or Institution, as each organization is shaped by different variables within itself. When enough research results emerge, these results will be the basis for the meta-analysis.

Finally, revising and modifying "sabotage" and "theft" subscales used in this study as components of CWB, will contribute to the literature considering labor market conditions, culture and social dynamics of Turkey. In this context, it would be more useful to examine and measure behaviors such as "sabotage" and "theft" by asking the participant indirectly, just as in measuring racism, sexism.

\section{References}

Abraham, R. (2000). Organizational Cynicism: Bases and Consequences. Genetic, Social and General Psychology Monographs. 126(3). Ağustos. 269-292.

Ambrose, M. L., Seabright, M. A., \& Schminke, M. (2002). Sabotage in The Workplace: The Role of Organizational Injustice. Organizational Behavior and Human Decision Processes. 89(1). 947-965.

Avşaroğlu, S., Deniz, M. E., \& Kahraman, A. (2005). Teknik Öğretmenlerde Yaşam Doyumu İş Doyumu ve Mesleki Tükenmişlik Düzeylerinin İncelenmesi. Selçuk Üniversitesi Sosyal Bilimler Enstitüsü Dergisi. 14(115-129).

Bernerth, J. B., Armenakis, A. A., Feild, H. S., \& Walker, H. J. (2007). Justice, Cynicism, and Commitment: A Study of Important Organizational Change Variables. The Journal of Applied Behavioral Science. 43(3). 303-326.

Blau, P. (1964). Power and Exchange in Social Life. New York: Wiley.

Bluedorn, A. C. (1982). A Unified Model of Turnover from Organizations. Human Relations. 35. 135-153.

Brandes, P. \& Das, D. (2006). Locating Behavioral Cynicism at Work: Construct Issues and Performance Implications. Employee Health, Coping and Methodologies içerisinde. Emerald Group Publishing Limited. 233-266.

Brandes, P.M. (1997). Organizational Cynicism: Its Nature, Antecedents and Consequences. Yayınlanmamış Doktora Tezi. Cincinnati: The University of Cincinnati.

Büyüköztürk, Ş. (2012). Sosyal Bilimler İçin Çok Değişkenli Istatistik: SPSS ve LISREL Uygulamalart. Ankara: Pegem Akademi Yayıncilık.
Byrne, Z.S., Hochwarter, W.A. (2008). Perceived Organizational Support and Performance Relationships Across Levels of Organizational Cynicism. Journal of Managerial Psychology. 23(1). 54-72.

Chiaburu, D. S., Peng, A. C., Oh, I. S., Banks, G. C. \& Lomeli, L. C. (2013). Antecedents and Consequences of Employee Organizational Cynicism: A Meta-Analysis. Journal of Vocational Behavior. 83(2). 181-197.

Çakar, N. D. \& Yıldız, S. (2009). Örgütsel Adaletin İş Tatmini Üzerindeki Etkisi: Algılanan Örgütsel Destek Bir Ara Değişken Mi? Elektronik Sosyal Bilimler Dergisi. 8(28). 69-90.

Çekmecelioğlu, H. G. (2005). Örgüt İkliminin İş Tatmini ve İșten Ayrılma Niyeti Üzerindeki Etkisi: Bir Araştırma. CÜ İktisadi ve İdari Bilimler Dergisi. 6(2). 23-39.

Dalal, R. S. (2005). A Meta-Analysis of the Relationship Between Organizational Citizenship Behavior and Counterproductive Work Behavior. Journal of Applied Psychology. 90(6). 1241-1255.

Dean Jr, J.W., Brandes, P. and Dharwadkar, R. (1998). Organizational Cynicism. The Academy of Management Review. 23(2). 341-352.

Eaton, J. A. (2000). A Social Motivation Approach to Organizational Cynicism. Yayınlanmamış Doktora Tezi. York University.

Eisenberger, R. and Armeli, S., Rexwinkel, B., Lynch, P. D. and Rhoades, L. (2001). Reciprocation of Perceived Organizational Support. Journal of Applied Psychology. 86(1). 42-51.

Eisenberger, R., Huntington, R., Hutchison, S. and Sowa, D. (1986). Perceived Organizational Support. Journal of Applied Psychology. 71(3). 500-507. 
Ersoy-Kart, M. (2015). Örgütsel Sinizm, Bağlamsal Performans ve Etik İdeoloji. Ankara: Nobel Yayincilik.

FitzGerald, M.R. (2002). Organizational Cynicism: It's Relationship to Perceived Organizational Injustice and Explanatory Style (Dissertation of Doctor of Philosophy). University of Cincinnati.

FoIger, R. \& Konovsky, M. A. (1989). Effects of Procedural and Distributive Justice on Reactions to Pay Raise Decisions. Academy of Management Journal. 32. 115-130.

Fox, S., Spector, P. E. and Miles, D. (2001). Counterproductive Work Behavior (CWB) in Response to Job Stressors and Organizational Justice: Some Mediator and Moderator Tests for Autonomy and Emotions. Journal of Vocational Behavior. 59. 291-309.

Gouldner, Alvin W. (1960). The Norm of Reciprocity: A Preliminary Statement. American Sociological Review. 25(161-178).

Göksu, T. (2007). Sosyal Psikoloji. Ankara: Seçkin Yayıncılık.

Güney, S. (2009). Sosyal Psikoloji. Ankara: Nobel Yayıncilik.

James, M. S. L. (2005). Antecedents and Consequences of Cynicism in Organizations: An Examination of the Potential Positive and Negative Effects on School System. Unpublished Doctoral Dissertation, ABD: The Florida State University.

Kağıtçıbaş1 Ç. (2013). Günümüzde İnsan ve Insanlar Sosyal Psikolojiye Giriş. İstanbul: Seçkin Yayıncılık.

Kalağan, G. \& Güzeller C. O. (2010). Öğretmenlerin Örgütsel Sinizm Düzeylerinin İncelenmesi, Pamukkale Üniversitesi Ĕgitim Fakültesi Dergisi.

Kalağan, G. (2009). Araştırma Görevlilerinin Örgütsel Destek Algıları ile Örgütsel Sinizm Tutumları Arasındaki Ilişki. Yayınlanmamış Yüksek Lisans Tezi. Antalya: Akdeniz Üniversitesi Sosyal Bilimler Enstitüsü.

Kilıç, S. (2013). Algllanan Örgütsel Etik İklim ile Üretkenlik Karşıtı İ̧ Davranışları Arasındaki Iliş̧kiler. Yayınlanmış Doktora Tezi. Niğde: Niğde Üniversitesi Sosyal Bilimler Enstitüsü.
Kraimer, M. L. and Wayne, S. J. (2004). An Examination of Perceived Organizational Support as a Multidimensional Construct in the Context of an Expatriate Assignment. Journal of Management. 30(209-237).

Lind, E. A., \& Tyler, T. R. (1988). The Social Psychology of Procedural Justice. New York: Plenum Yayıncılik.

Martin, C. L., \& Bennett, N. (1996). The Role of Justice Judgments in Explaining the Relationship Between Job Satisfaction and Organizational Commitment. Group \& Organization Management. 21(1). 84-104.

Martinko, M. J., Gundlach, M. J. \& Douglas, S. C. (2002). Toward an Integrative Theory of Counterproductive Workplace Behavior: A Causal Reasoning Perspective. International Journal of Selection and Assessment. 10 (1-2). 36-50.

Miao, R. T. (2011). Perceived Organizational Support, Job Satisfaction, Task Performance and Organizational Citizenship Behavior in China. Journal of Behavioral and Applied Management. 12(2). 105-128.

Moorman, R. H., Blakely, G. L. \& Niehoff, B. P. (1998). Does Perceived Organizational Support Mediate the Relationship Between Procedural Justice and Organizational Citizenship Behavior? Academy of Management Journal. 41(3). 351-357.

Mustaine, E. E. \& Tewksbury, R. (2002). Workplace Theft: An Analysis of StudentEmployee Offenders and Job Attributes. American Journal of Criminal Justice. 27(1). 111-127.

Nayır, F. (2013). Algılanan Örgütsel Destek Ölçeğinin Kısa Form Geçerlik Güvenirlik Çalışması. Mehmet Akif Ersoy Üniversitesi Ĕgitim Fakültesi Dergisi. 28. 89-106.

Neuman, J. H. \& Baron, R. A. (1997). Aggression in the Workplace. Antisocial Behavior in Organizations. 37-67.

Neves, P. (2012). Organizational Cynicism: Spillover Effects on Supervisorsubordinate Relationships and Performance. The Leadership Quarterly. 23. 965-976.

OED (2019). [https://en.oxforddictionaries.com/ definition/cynicism]. (Erişim: 24.08.2019) 
The Role of Organizational Cynicism as a Mediator in the Relationship Between Perceived Organizational Support and Counter Productive Work Behavior for Public Employees

O'Hair, D., \& Cody, M. J. (1987). Machiavellian Beliefs and Social Influence. Western Journal of Communication (Includes Communication Reports). 51(3). 279-303.

Özdevecioğlu, M. (2003). Algılanan Örgütsel Adaletin Bireylerarası Saldırgan Davranışlar Üzerindeki Etkilerinin Belirlenmesine Yönelik Bir Araştırma. Erciyes Üniversitesi İktisadi ve İdari Bilimler Fakültesi Dergisi. (21). 77-96.

Pearson, C. M., Andersson, L. M. and Porath, C. L. (2005). Workplace Incivility içerisinde S. Fox ve P. E. Spector (Ed). Counterproductive Work Behavior: Investigations of Actors and Targets. 177-200.

Rhoades, L. \& Eisenberger, R. (2002). Perceived Organizational Support: A Review of the Literature. Journal of Applied Psychology. 87(4). 698-714.

Robinson, S. L. \& Bennett, R. J. (1995). A Typology of Deviant Workplace Behaviors: A Multidimensional Scaling Study. Academy of Management Journal. 38(2). 555-572.

Sackett, P.R. (2002). The Structure of Counterproductive Work Behaviors: Dimensionality and Relationships with Facets of Job Performance. International Journal of Selection and Assessment. 10(1/2). 5-11.

Schneider, B. \& Snyder, R. A. (1975). Some Relationships between Job Satisfaction and Organization Climate. Journal of Applied Psychology. 60(3). 318.

Skarlicki, D. P., Van Jaarsveld, D. D., \& Walker, D. D. (2008). Getting Even for Customer Mistreatment: The Role of Moral Identity in the Relationship between Customer Interpersonal Injustice and Employee Sabotage. Journal of Applied Psychology. 93(6). 1335.

Spector, P. E. (2000). Industrial and Organizational Psychology: Research and Practice (2.b.). New York: John Wiley \& Sons, Yayıncilık.

Spector, P. E. (2011). The Relationship of Personality to Counterproductive Work Behavior (CWB): An Integration of Perspectives. Human Resource Management Review. 21(4). 342-352.

Spector, P.E. \& Fox, S. (2002). An EmotionCentered Model of Voluntary Work Behavior: Some Parallels between Counterproductive Work Behavior and Organizational Citizenship Behavior. Human Resource Management Review. 12(2). 269-92.
Spector, P.E., Fox, S.; Penney, L.M.; Bruursema, K; Goh, A., Kessler, S. (2006). The Dimensionality of Counterproductivity: Are All Counterproductive Behaviors Created Equal? Journal of Vocational Behavior. 68. 446-460.

TDK (2019). Sinizm Tanımı. [http://www.tdk. gov.tr/index.php?option=com_gts\&arama=gts \&guid=TDK.GTS.580cff050ed408.78977704]. (Erişim: 23.08.2019).

Tokgöz, N. \& Y1lmaz, H. (2008). Örgütsel Sinizm: Eskişehir ve Alanya'daki Otel İşletmelerinde Bir Uygulama. Anadolu Üniversitesi Sosyal Bilimler Dergisi. 8(2). 283305.

Tokgöz, N. (2011). Örgütsel Sinizm, Örgütsel Destek ve Örgütsel Adalet İlişkisi: Elektrik Dağıtım İşletmesi Çalışanları Örneği. Eskişehir Osmangazi Üniversitesi İktisadi ve İdari Bilimler Dergisi. 6(2). 363-387.

Turunç, Ö. \& Çelik, M. (2010). Çalışanların Algiladiklari Örgütsel Destek ve İs Stresinin Örgütsel Özdeşleşme ve İş Performansına Etkisi, Yönetim ve Ekonomi. Celal Bayar Üniversitesi İktisadi ve İdari Bilimler Fakültesi Dergisi. 17(2). 183-206.

Ünal, S., Karlıdağ, R. \& Yoloğlu, S. (2001). Hekimlerde Tükenmişlik ve İş Doyumu Düzeylerinin Yaşam Doyumu Düzeyleri ile İlişkisi. Klinik Psikiyatri. 4(2). 113-118.

Yazıcıoglu, Y. ve Erdoğan, S. (2004). SPSS Uygulamalı Bilimsel Araştırma Yöntemleri. Ankara: Detay Yayıncilık. 
